\title{
Issues, Challenges and Problems with Tax Evasion: The Institutional Factors Approach
}

\author{
Mohd Rizal Palil,,$^{*}$ Marlin Marissa Malek, ${ }^{2}$ and Abdul Rahim Jaguli ${ }^{2}$ \\ ${ }^{1}$ Faculty of Economics and Business, University Kebangsaan Malaysia \\ ${ }^{2}$ School of International Studies, Universiti Utara Malaysia
}

\begin{abstract}
Tax evasion, particularly in developing countries is a debatable issue. Evasion is a disease and needs to be minimized so that the black economy or hidden economy can be mitigated. This paper attempts to reveal the determinants of tax evasion from the institutional perspectives. The objective of this study is to identify the determinants of tax evasion a decade after the introduction of a Self-Assessment System (SAS). Three institutional perspectives of the determinants of tax evasion were examined, namely the probability of being detected, the role of the tax authority and the complexity of the tax system. The results suggested that the complexity of the system, and the probability of being detected had a significant impact on tax evasion. The results of this study could possibly contribute to the body of knowledge in lieu of combating tax evasion, as well as being an input to tax administrators and policymakers into which ways the determinants can affect compliance. The findings also provide an indicator for tax administrators of the relative importance of the tax system in assisting with the design of tax education programs, simplifying tax systems and developing a wider understanding of taxpayers' behavior.
\end{abstract}

Abstrak: Penggelapan pajak, khususnya di negara-negara berkembang adalah isu yang dapat diperdebatkan. Penggelapan adalah penyakit dan harus diminimalkan sehingga ekonomi hitam atau ekonomi tersembunyi dapat dimitigasi. Paper ini mencoba untuk mengungkapkan beberapa determinan penggelapan pajak dari perspektif kelembagaan. Tujuan penelitian ini adalah untuk mengidentifikasi berbagai determinan penggelapan pajak satu dekade setelah pengenalan Self-Assessment System (SAS). Tiga perspektif kelembagaan determinan penggelapan pajak dikaji, yaitu probabilitas terdeteksi, peran autoritas pajak, dan kompleksitas sistem pajak. Hasil penelitian menunjukkan bahwa kompleksitas sistem, dan probabilitas dapat terdeteksi berdampak signifikan pada penggelapan pajak. Hasil penelitian ini mungkin dapat berkontribusi pada pokok ilmu pengetahuan sebagai pengganti memerangi penggelapan pajak, serta menjadi masukan untuk administrator pajak dan pembuat kebijakan tentang cara-cara beberapa determinan mempengaruhi kepatuhan. Temuan ini juga memberikan indikator untuk administrator pajak penyederhanaan pentingnya relatif sistem pajak dalam membantu dengan desain program pendidikan pajak, penyederhanaan sistem pajak dan pengembangan pemahaman yang lebih luas tentang perilaku pembayar pajak.

Keywords: black economy; hidden economy; institutional factors; self assessment system; tax evasion

JEL classification: $\mathrm{H} 25, \mathrm{H} 26, \mathrm{~K} 2$

* Corresponding author's e-mail: mr_palil@ukm.edu.my

ISSN: $1141-1128$

http://journal.ugm.ac.id/gamaijb 


\section{Introduction}

Paying taxes is not a favorite of all of us, but for the government, and in particular its revenue agencies, tax collection is an important activity. Many of us would argue why must we pay taxes? In what ways does the amount paid in taxes benefit us as a nation? Understanding the spirit behind the tax payment is vital. Tax is defined as a compulsory payment to the authorized bodies and yet no implicit rewards are received by the payer (Lymer and Oats 2009).

On the other hand, avoiding tax liabilities could be defined in various ways. Tax evasion or non-compliance describes a range of activities that are unfavorable to a state's tax system. These include tax avoidance, which refers to reducing taxes by legal means, and tax evasion which refers to the criminal non-payment of tax liabilities. Groups that do not comply with taxes include tax protesters and tax resisters. Tax resisters typically do not take the position that the tax laws are themselves illegal or do not apply to them, and they are more concerned with not paying for the particular government policies that they oppose. Tax protesters attempt to evade the payment of taxes by using trivial interpretations of the tax laws, whilst tax resisters refuse to pay a tax for conscientious reasons.

The exact meaning of tax evasion has been defined in various ways. Tax evasion is defined by the United States' Internal Revenue Service (IRS) as an intentional misrepresentation of material facts, performed by the taxpayer with the specific purpose of evading a tax known or believed to be owed. Tax avoidance on the other hand is defined as being intentional, since an act of compliance requires both a tax being due and owed and a fraudulent intent not to pay it (Ritsatos
2014). Previously, James and Alley (2004) asserted that noncompliance is more than tax evasion and it also includes some forms of tax avoidance. James and Alley define tax evasion as 'The attempt to reduce tax liability by illegal means' while tax avoidance is defined as 'reducing taxation by legal means' (p. 28). Lewis (1982: 123) perceived tax evasion as 'any legal method of reducing one's tax bill' and tax evasion is 'illegal tax dodging.' Similarly, Kasipillai, Aripin and Amran (2003) perceived tax evasion as actions which result in lower taxes than are actually owed (p. 135) while tax avoidance denotes the taxpayers' creativity in arranging his tax affairs in a proper manner based on the laws and regulations (any provisions not being violated) so as to reduce his tax bill, and this is (or should be) acceptable in the view of the tax administrator. Kasipillai et al. (2003); Lewis (1982); Webley (2004); Elffers et al. (1987) and Andreoni et al. (1998), Ritsatos (2014) and Stack (2015) express that noncompliance includes both intentional and unintentional actions. The latter are normally due to calculation errors and inadequate tax knowledge although there are other determinants.

Boll (2015) outlined two major distinctions in intentional tax evasion: 1) Evasion by commission and 2) evasion by omission. Evasion by commission requires an action by the taxpayer, for example claiming deductions or rebates which mean that if a taxpayer is making a false claim, he will get a tax saving (a commission on top of his evading actions). Conversely, evasion by omission is intentional and should be classified as seriously as evasion by commission (Lewis 1982). This kind of evasion requires taxpayers to do nothing in the tax return (i.e miss something out deliberately); for example, one would not report his casual income or any cash-based income. 
Tax evasion or noncompearance is also influenced by the intention to disobey (Damayanti et al. 2015; Aini et al. 2013; Ernawati and Purnomosidhi 2011).

Defining tax evasion and tax avoidance is important as it will differentiate between legal and illegal actions taken by a person. The negative impacts of evading taxes are various, for example, the national revenues would decrease significantly and thus encouraging a hidden economy in which inequities in the economy would be derived. Judging from the negative impacts of tax evasion, this paper attempts to provide some measures in order to reduce tax evasion rates in a developing country. The focal point of the study is on Malaysia, a developing country which has implemented a self-assessment system, a system believed to be highly dependent on the honesty of the taxpayers in determining their tax liabilities.

\section{Understanding People's Behavior Toward Taxes}

First and foremost, a government should understand the nation's behavior towards taxes so that the nation would willingly pay the taxes owed. Paying taxes is a voluntary act, even though it is made compulsory by virtue of the laws and regulations passed about this. As tax payments require a high financial commitment in various countries, especially in developing countries, many taxpayers are keen to evade taxes rather than paying the exact amount of tax. Although many previous studies have suggested various determinants which influenced tax evasion, tax evasion is still present in the system and this could reduce national revenues and subsequently diminish national development. Based on Kirchler (2007) the determinants of tax evasion could be divided into four main parts, namely 1) economic factors (tax rates, tax audits and perceptions of government spending); 2) institutional factors (the role of the tax authority, the complexity of the tax returns and their administration, and the probability of detection); 3) social factors (ethics and attitude, perceptions of equity and fairness, political affiliation and changes in current government policies, referent groups); and 4) individual factors (personal financial constraints, an awareness of the offences and penalties).

For example, Kirchler (2007: 3) divided tax evasion determinants into five categories and his study was based on psychological and the tax authority-taxpayers' views namely, the political perspectives, the social psychological perspectives, the decision making perspectives, self-employment and the interaction between the tax authorities and taxpayers. However, discussing all four categories of tax evasion determinants would make this paper unfocused; therefore, this paper will only discuss tax evasion from the institutional perspectives. While taxpayers are influenced by pure economic concerns to either evade or not evade taxes, evidence suggests that institutional factors also play an important role in their compliance decisions. The institutional factors discussed in this section include the taxpayers' perceptions of the efficiency of the tax authority/government, the complexity of the tax returns and the tax system generally, as well as the probability of being detected.

\section{Role (efficiency) of the tax authority/ government}

The role of the tax authority in minimizing the tax gap and increasing voluntary compliance is clearly very important. In addition, as an agent of collection, the perception of the taxpayers towards the government 
is important. There is a debate in the literature as to how the effective operation of the tax system by the tax authorities influences the taxpayers' compliance behavior. Researchers from different countries have also been unable to achieve agreement about this issue, which appears to differ from country to country. In the US for example, the IRS views tax noncompliance as a big challenge, as the tax gap has increased tremendously in the last few decades. In 1976, an IRS report estimated under reported income was $\$ 75$ to $\$ 100$ billion - about 7 percent to 9 percent of the reported income (IRS 1979a: 11). While Guttman (1977) and Fiege (1979) estimated that in reality it was probably higher than this. Guttman (1994) revealed that in 1993 the tax gap in the US was more than $\$ 170$ billion (around a $70 \%$ to $126 \%$ increase compared to the IRS estimate in 1976). Different countries have proposed and developed different solutions for the relationship between the taxpayers' compliance and their operation of the tax system.

In Belgium for instance, the total amount of tax being evaded was estimated at 20 percent of the income tax (Hasseldine 1993) while across the US, Australia, the Netherlands and Sweden, surveys revealed that one quarter of the respondents admitted that they deliberately under-reported their income (Hasseldine 1993). Hasseldine and Li (1999) illustrated that the government and the tax authorities were the main parties that needed to be continuously efficient in administering the tax system in order to minimize tax evasion. Hasseldine and $\mathrm{Li}$ also claimed that governments play a central role through designing the tax systems, and the specific enforcement and collection mechanisms (Hasseldine and Li 1999: 93).
A study conducted by Richardson (2008) investigated the determinants of tax evasion across 47 countries including the USA, the UK, Argentina, Thailand, Canada, Chile and Brazil also suggested that governments have a significant positive impact on determining tax evasion. Richardson also suggested that governments should increase their reputations and credibility in order to obtain trust from their taxpayers. Furthermore, Roth et al. (1989) suggested that in order to increase compliance, maximize tax revenues and be respected by the taxpayers, a government must first have an economical tax system, which is practicable ${ }^{1}$; they must discourage tax evasion and not induce dishonesty; they must avoid the tendency to dry up the sources of the taxes and should avoid provoking conflict and raising political difficulties; they should also have a good relationship with the international tax regimes. In summary, although previous studies (for example Roth et al.; Richardson and Hasseldine and $\mathrm{Li}$ ) could not provide conclusive results on the measurable impact of the efficiency of the governments on compliance, however, researchers from different countries have discussed this issue and some authors have describe how the role of governments in inducing tax evasion is important and relevant to self-assessment systems (see Richardson 2008; Hasseldine and Li 1999).

A study by Stack (2015) in Ukraine found that another issue related to tax evasion was that the level of money laundering activities had increased tremendously since 2007 in the Ukraine. For example two UK companies and one Cypriot company transferred a total of $€ 172.5$ million and $\$ 332.2$ million from bank accounts in a Latvian bank to their accounts in a Ukrainian bank to le-

${ }^{1}$ The government have suitable powers (assessment and collection) to administer the tax system . 
galize their funds in the economy. As these funds were the product of tax evasion in the UK, the illegal money was then transferred to local people by creating some ordinary transactions, including payments in response to shareholding activities in three Ukrainian companies. On the other hand, a South African firm and a UK firm transferred from accounts at the same Latvian bank a total of $\$ 548.2$ million and $€ 204.4$ million to the accounts of a Russian in a Ukrainian bank as an advance (loan) to the respective parties and the parties were then to legalize the money by spending it in the Ukrainian economy.

\section{Probability of detection/audited}

Slemrod et al. (1998) investigated the relationship between the probability of being detected and the taxpayers' responses. The experiment ${ }^{2}$ indicated that taxpayers' behavior varied with respect to their level of income and the probability of being detected. The later dimension (probability of being detected) played a significant role in determining the taxpayers' evasive behavior. However, the direction of the relationship (positive or negative) was not clearly stated by Slemrod et al. (1988). Moreover, compliance in respect to the probability of detection ${ }^{3}$ has received attention from many researchers including Allingham and Sandmo (1972) who claimed that taxpayers will always declare their income correctly if the probability of detection is high. The probability of detection plays a significant role in reporting behavior as taxpayers will declare everything if they perceive that they will be one of the auditees in that particular year (RiahiBelkaoui 2004; Richardson 2008).

A study by Eisenhauer (2008), investigated tax evasion determinants particularly in terms of ethical preferences and risk aversion (high or low audit probability) using three major data sources: Surveys, audits and experiments, across the United States. The study also suggested that due to increased evasion across the USA, tax audits have become more important as a way of minimizing tax noncompliance. However, the importance of the audit programs was not solely determined by the individuals who were self-employed taxpayers (as suggested by this study); other groups of taxpayers (for example employees) might provide different results and interpretations. The study concluded that individuals who are self-employed have a greater opportunity to evade than other groups, especially in light of the low probability of audits that they faced, coupled with less third-party withholding of their income tax liabilities. In summary, different levels of probability of detection provide different degrees of compliance. For example, a high probability of detection potentially increases compliance (see Bergman 1998; Eisenhauer 2008), although some authors found contradictory results in some circumstances (i.e. Young 1994: Slemrod et al. 2001).

\section{Complexity of the tax systems and its administration}

Another variable under the institutional factors determining tax evasion is the complexity of the tax systems. How does a complex tax system discourage people from pay-

\footnotetext{
${ }^{2}$ Using tax returns from two years to compare the differences in reported income, deductions and tax liabilities. Random sampling was used.

${ }^{3}$ The degree or probability rate is defined as the number of tax returns audited divided by total tax returns received by the tax authority.
} 
ing taxes? As tax systems have become increasingly more complex over time in many developed countries, complexity has become an important determinant of tax evasion behavior. The main feature of a SAS is the selfcompleted tax return which requires at least a reasonable level of complexity because taxpayers come from various backgrounds, with differing levels of income, levels of education, and most importantly levels of tax knowledge. In helping taxpayers to complete their tax returns accurately, the tax authorities should have come up with a simple, but comprehensive, tax return and administration system. The information required in the return must be at the minimum level needed, and be readily available from taxpayers' business and personal records.

Silvani and Baer (1997) discussed the importance of the tax authority having a simple tax return and system from the taxpayers' point of view. The tax authority may assume its tax return is simple and easy to complete but it may not be from the taxpayers' point of view Although the word 'simple' carries multiple interpretations, the majority of taxpayers require that the tax return should be as simple as possible. Therefore, it is good practice, before the final version is delivered to taxpayers, to ensure that 'pilot' tests have taken place first so that the tax return is really as simple and easy as it can be.

Some countries for example Denmark, Canada and New Zealand have been developing their tax systems to be more taxpayerfriendly. They have introduced simplified tax returns by reducing the number of pages to facilitate and increase voluntary compliance among taxpayers (Mohani 2001: Mohani and Sheehan 2003, 2004). In the UK for example, HMRC has tried to present more simplified tax returns that ordinary people can understand better. In 2007, the tax return was ac- companied by a 35 page guide on how to complete the tax return and that did not even include the 8 extra pages of notes that also needed to be considered by some taxpayers (HMRC 2009). The form and its accompanying guide has now been simplified to facilitate taxpayers, in particular by computerizing this process so that only context-sensitive details are needed as the taxpayers complete their returns. This significantly simplified the range of guidance the taxpayer is exposed to, keeping it to the necessary minimum.

Another point of view is that by simplifying the tax return, this will encourage taxpayers to complete the tax return on their own rather than employing a tax agent and thus reducing the compliance costs (Silvani and Baer 1997). Previous studies have evidenced that the complexity of the reporting requirements had a high association with the errors detected by audits (Long 1988). This finding (by Long) is perhaps to be expected by the tax authorities. If many errors are detected in tax returns and the same errors are made every year by different taxpayers, it means that the wording or the sentences, or even the format of the tax return may at least be partly to blame. Slemrod (1989) makes a similar point to Long (1988) in that he believes that a simple tax return and simpler tax regulations could possibly decrease tax evasion especially in a self-assessment system.

A recent study conducted by Isa (2015) aims to examine the difficulties encountered by corporate taxpayers in complying with tax obligations under the self-assessment system in Malaysia. Three determinants of the tax complexity were the tax calculations, the record keeping requirements and ambiguities in the taxes. Isa (2015) found that the tax calculations and record keeping were the biggest problems encountered by small firms in 
Malaysia while the third determinant - ambiguity in the taxes, was normally faced by medium and large scale firms. The complexity of a tax system is believed to be one of the determinants in cultivating tax evasion (Isa 2015: 51) particularly in developing countries with moderate levels of education. Isa (2015) then suggested that in order to minimize tax evasion among corporate taxpayers, the simplicity of the tax system plays a major role. Simpler and clearer tax systems would provide lower compliance costs, hence reduce tax evasion activities. Therefore, Isa (2015) suggested that the tax authority should simplify the tax system, including simplifying the preparation of tax computations, standardize procedures for record keeping and formulate clearer tax laws to reduce tax ambiguities.

Simplifying tax administration is important because it can facilitate efficient and enhanced administration and reduce costs (Mohani 2001; Bird 1998; Silvani and Baer 1997). In practice, the current stipulated law and regulations might no longer be relevant in the future. For example, personal allowances, deductions, tax rates, tax reliefs, taxable income and rebates are usually different each year. Tax regulations and their laws in most countries are amended almost every year as part of the annual budget process, this situation encourages taxpayers to make mistakes. Thus, noncompliance in terms of inaccurate tax returns is not only caused by the taxpayers evasive behavior (either intentional or unintentional), but may also be because of the tax authority's mistakes or weaknesses in developing and designing the systems.

Interestingly, Richardson (2008) in his study which extended studies by RiahiBelkaoui (2004) and Jackson and Milliron (1986), found that out of seventeen variables tested across 45 countries (including age, gen- der, education, fairness, culture and religion), complexity was found to be the most important determinant of tax evasion (p. 164). He therefore concluded that 'A more simple tax system and administration can reduce tax evasion' (p.165). In summary, as the main feature of the SAS is the self-completed tax returns and the taxpayers come from various backgrounds and levels, therefore simplifying the tax returns and the administration potentially could help taxpayers to complete their tax returns accurately and increase compliance. The next subsection describes the relationship between the probability of detection and compliance.

\section{Hypotheses Development}

\section{Hypotheses 1}

As per the discussion in section 2 , institutional factors can be classified into three determinants, namely the role of the tax authority, the complexity of the tax system and the probability of detection. To date, no conclusive evidence has proven how tax authorities can influence taxpayers' compliance behavior, as researchers from different countries were unable to reach agreement on this issue. The role of the tax authority in minimizing the tax gap and increasing voluntary compliance is very important, as Hasseldine and $\mathrm{Li}$ (1999) placed the government and the tax authority as the main parties that needed to be continuously efficient in administering the tax system in order to minimize tax evasion. In the US for example, the IRS view tax noncompliance as a big challenge and has had to deal with this carefully as the tax gap has increased tremendously in the last decade. The government plays the central role in designing the tax systems, and the enforcement and collection methods (Hasseldine and $\mathrm{Li}$ 
1999: 93). Furthermore, Roth et al. (1989) suggested that in order to increase compliance, maximize tax revenues and be respected by taxpayers, a government must first have an economical tax system which is practical ${ }^{4}$; they must not provoke conflicts and raise political difficulties, and should have a good relationship with the international tax regimes. In addition, they must discourage tax evasion and induce honesty, while avoiding the tendency to dry up the sources of tax. A study conducted by Richardson (2006) also suggested that the role of the government has a significant impact on determining attitudes towards taxes. A simpler tax system introduced by a government can reduce tax evasion. Therefore, following the above discussions, it is hypothesized that:

$H_{1}$ : The role (efficiency) of the tax authority is negatively correlated with tax evasion.

\section{Hypotheses 2}

Compliance in relation to the probability of being detected has received attention from many researchers. An earlier study by Allingham and Sandmo (1972) claimed that taxpayers will always declare their income correctly if the probability of detection is high. Slemrod, Blumenthal and Christian (2001) investigated the relationship between the probability of being detected and the taxpayers' responses. The experiment ${ }^{5}$ indicated that taxpayers' behavior varied in terms of their level of income and the probability of being detected, which played a significant role in determining taxpayers' evasion behavior. The probability of detection plays a signifi- cant role in the reporting behavior as taxpayers will declare everything if they perceive that they will be one of the auditees in that particular year (Riahi-Belkaoui,2004; Richardson 2006). However, the direction of the relationship (positive or negative) was not clearly stated by Slemrod et al. (1998). This result (by Slemrod et al.) was also supported by Andreoni et al. (1998) who also found that a prior audit experience influenced and decreased tax evasion. Conversely, Young (1994) and Slemrod, Blumenthal and Christian (2001) found that the probability of being detected negatively correlated with compliance behavior.

Another study by Yusof et al. (2014) attempted to determine the role of audits in corporate tax noncompliance among Small and Medium sized Corporations (SMCs) in Malaysia. They suggested that the determinants included marginal tax rates, company size and the types of industry exerted significant effects on corporate tax evasion. The main sectors where tax evasion was encountered were in the construction and the service industries. The amount of concealed income unearthed during tax audits clearly indicated that there was widespread tax noncompliance in Malaysia and the quantum of tax lost through tax noncompliance was quite high. Therefore, following the above discussions, as well as taking into consideration Malaysia's economic environment and culture, it is hypothesized that:

\section{$H_{2}$ : The probability of being detected is negatively correlated with tax evasion.}

\footnotetext{
${ }^{4}$ The government have suitable powers (assessment and collection) to administer the tax system .

${ }^{5}$ Using taxpayers' tax returns for two years to compare the differences in reported income, deductions and tax liabilities. Random sampling was used.
} 


\section{Hypotheses 3}

As tax systems have become increasingly more complex over time in many developed countries, complexity has become an important determinant of tax compliance behavior in view of the institutional factors. The main feature of the SAS is the self-completed tax returns which require at least a reasonable level of complexity because taxpayers come from various backgrounds, with differing levels of income, education, and levels of tax knowledge. In helping taxpayers to complete the tax returns accurately, the tax authority should have come up with a simple, but comprehensive, tax return. The information required in the return must be at the minimum necessary level and be readily available from taxpayers' business and personal records.

As the tax regulations and laws in most countries are amended almost every year as part of their annual budget process, the current regulations might no longer be relevant in the future. For example, tax rates, personal allowances, deductions, rebates and taxable income are usually different each year. This situation will encourage the taxpayers to make mistakes. Simplifying the tax administration is important because it can facilitate efficient and enhanced administration and reduce costs (Mohani 2001; Bird 1998; Silvani and Baer 1997). Thus, noncompliance in terms of inaccurate tax returns is not only caused by taxpayers evasive behavior (either intentional or unintentional), but may also be because of the tax authority's mistakes or weaknesses in developing and designing the systems. Richardson (2008) in his study which extended the studies by Riahi-Belkaoui (2004) and Jackson and Milliron (1986), found that out of seventeen variables tested across 45 countries (including age, gender, education, fairness, culture and religion), complexity is found to be the most important determinant of tax evasion (p. 164).

He therefore concluded that 'a more simple tax system and administration can reduce tax evasion' (p.165). Isa (2015) aimed to examine the tax difficulties encountered by corporate taxpayers in complying with their tax obligations under the self-assessment system in Malaysia. Three determinants of tax complexity were the tax calculations, the required record keeping and tax ambiguities. Isa (2015) found that the tax calculations and record keeping were the biggest problems encountered by small firms in Malaysia while the third determinant - tax ambiguity was normally faced by medium and large sized firms. The complexity of a tax system is believed to be one of the determinants in cultivating tax evasion (Isa 2015: 51) particularly in a developing country with a moderate level of education. Therefore, following the above discussions, it is hypothesized that:

$H_{3}:$ A simple tax return and tax system is negatively correlated with tax evasion.

\section{Methods}

\section{Sampling and Data Collection}

The main objective of this study is to determine the factors involved in tax evasion by focusing on the institutional perspectives. The data were collected through a national survey. A total number of 5,500 mail surveys were distributed to individual taxpayers throughout Malaysia, who were selected at random from telephone directories. Prior to that, a pilot survey on a group of 23 lecturers and professionals in various sectors and members of the general public (non-tax specialists) was conducted to improve the validity and reliability, as well as to further refine 
the questions. Kasipillai and Baldry (1998) asserted that the selection of samples from local telephone directories may exclude low income earners who are less likely to have a telephone.

This suggestion was supported by Wang and Saunders (2012) who used telephone directories to select their sample in their study on Chinese managers in China. Moreover, Calvert ad Pope (2005) and Forza (2002) were using telephone directories as their database for data collection. However, in the Malaysian context two factors help to overcome this potentially results-biasing position. Firstly, phone ownership is very high and no 'ex-directory' service is available whereby numbers could be unlisted (as typical in the UK for example) Secondly (and perhaps more importantly), in Malaysia, many since low income earners are unlikely to lodge tax returns using the Malaysian SAS, their possible exclusion from this survey is not considered to be of major concern, given that the focus is on taxpayers who have had direct experience of the SAS. An individual who earns less than RM25,501 (USD8,226) per annum does not have to submit a tax return (IRB 2014). Therefore, taken all together, this sampling method, in this context, leads to a good randomization with few limitations compared to other sampling approaches for this scale of survey. ${ }^{6}$

Taking the sample from a telephone directory is, however, limited in one key output that may alter our results, namely the possibility of the impact of the growth in mobile phone ownership which is becoming significant in Malaysia. Malaysia has the sec- ond highest mobile penetration in South East Asia, after Singapore (South East Asian Mobile Communications \& Mobile Data Markets Report 2013). In early 2006, mobile penetration passed the 80 percen mark, with subscriber numbers at the same time passing 20 million. ${ }^{7}$ This was up from only 2 million subscribers in 1998. Although the growth of mobile telephones is significantly higher than that of landlines, the ownership of landlines is both classical and traditional - to own a landline is still considered necessary even in households which possess more than one mobile.

\section{Questionnaire Design, Variables Development and Measurement}

The questionnaire was prepared in both Malay and English versions (in the same booklet) to facilitate respondents and was divided into four sections:

\section{Section A - Tax compliance hypothetical questions}

This section consisted of eight hypothetical questions related to tax compliance behavior. It was developed based on Troutman (1993) and Chan et al. (2000). The development of hypothetical questions was also based on the Choice of Dilemma Questionnaire (CDQ) developed by Kogan and Wallach (1964). Kogan and Wallach introduced a series of CDQ questions to examine human resources risk-based decision making as follows: The central person (based on Kogan and Wallach) in each situation is faced with a choice between two alternative courses of action. Alternative $\mathrm{X}$ is more desirable

\footnotetext{
${ }^{6}$ Alternatively, a list of taxpayers could be obtained from the tax authority. However, it is very difficult to obtain the list as the tax authority is not allowed by the Income Tax Act 1967 to reveal any taxpayers information to the public.

7 Total population in 2000 was 23.27 million compared to 18.38 in 1990 (27.15\% increase) (The Population and Housing Census 2000). This figure increased to 27.46 million in 2008 (Malaysia Department of Statistics, 2008).
} 
and attractive than alternative $\mathrm{Y}$, but the probability of achieving $\mathrm{X}$ is less than that of achieving Y. For each situation, respondents are asked to indicate the minimum probability of success they would require before recommending that alternative $\mathrm{X}$ be chosen. Respondents are asked to indicate their choice on a ten-point scale that ranges from 1 (risk averse) to 10 (risk seeker). Responses from this instrument are summed to derive a relative measure of a risk aversion personality. The CDQ test has been used in various studies such as decision making (risk taking) by Cartwright (1971), and human resources management (Nutt 1986).

The choice-dilemma paradigm that CDQ is based upon is also suitable to be used in this study. However, some modifications of the hypothetical questions have been undertaken so that the variables used in this study were in line with the research questions. The degree of adaptation of Kogan and Wallach's CDQ was limited to the style of the questionnaire's development, as it did not focus on moral reasoning or risk aversion. For example, respondents were required to indicate their actions in relation to tax compliance behavior (i.e does the probability of being audited encourage taxpayers to be more compliant?)

\section{Section B - Tax knowledge questions}

Section B of the questionnaire consisted of 37 questions related to the respondent's level of tax knowledge and was primarily based on Section 4 (a) to (f) of the Income Tax Act $1967^{8}$ as well as studies con- ducted by Harris (1989); Eriksen and Falllan (1996); Loo (2006); Loo and Ho (2005). (See also Mohamad Ali et al. (2007) and Devos (2008) who also used a similar approach). Harris (1989) conducted an experiment (the association between tax knowledge and the perception of the fairness of the tax system) using video, divided into two phases. Each subject was given 10 scenarios using a 10 point Likert scale ranging from 0 ('allowing this deduction is extremely unfair') to 10 ('allowing this deduction is extremely fair'). Eriksen and Fallan (1996) in their quasi-experiment measured tax knowledge by pre and post experiment testingtax knowledge using a score calculated from 12 questions (posttest 28 questions) related to tax allowances and tax liabilities. Instead of a 5 point Likert scale, Eriksen and Fallan used 'Yes', 'No' and 'Do not Know' scales in measuring the level of tax knowledge. Those who answered 'Do not know' would receive a score of 2 .

\section{Section C - Tax compliance direct questions}

Section C consisted of 26 direct questions related to tax compliance behavior. The variables (i.e. the predictors being explored) remained the same as in Section A (hypothetical questions). This section was developed to examine the taxpayers' responses to direct questions, to complement the hypothetical questions in Section A as well as to enhance the validity and reliability of the data obtained from Section A's questions. This 'direct questions' approach was based on Troutman (1993) and Chan et al. (2000). A comparison of the results for both Section A and C will

\footnotetext{
${ }^{1}$ Section 4. Classes of income on which tax is chargeable.

"Subject to this Act, the income upon which tax is chargeable under this Act is income in respect of: (a) gains or profits from a business, for whatever period of time carried on; (b) gains or profits from an employment; (c) dividends; interest or discounts; (d) rents, royalties or premium; (e) pensions, annuities or other periodical payments not falling under any of the foregoing paragraphs; (f) gains or profits not falling under any of the foregoing paragraphs."
} 
be made in the following chapter. This section required the respondents to answer using a Likert scale ranging from 1 ('strongly disagree') to 5 ('strongly agree') ${ }^{9}$

\section{Section D - Respondents' background}

The final section (Section D) consisted of the demographic variables including age, gender, income, educational background, and some background information on the respondent's tax history. These variables became the independent variables in further analysis so that an association between these demographic variables and tax knowledge and tax compliance could be analyzed.

A total of three tax compliance determinants (independent variables) were examined as illustrated in Table 1, namely the prob- ability of being detected (E1), the role of the tax authority (E2) and the complexity of the tax system (E3).

To test the hypotheses as outlined in Section 3, the data was analyzed using multiple regressions [Ordinary Least Squares (OLS)]. Equation 1 was used as the base regression model to test the hypotheses and establish the tax evasion determinants.

$$
\begin{aligned}
\text { TE }_{\mathrm{i}}= & \alpha+\beta_{1} \text { PROBDETECT }_{\mathrm{i}}+ \\
& \beta_{2} \text { ROLE }_{\mathrm{i}}+\beta_{3} \text { SIMPLE }_{\mathrm{i}}+\varepsilon_{\mathrm{i}}
\end{aligned}
$$

where, $\mathrm{TE}_{\mathrm{i}}$ is tax evasion score; PROBDETECT $T_{i}$ is Probability of being detected; ROLE $\mathrm{i}_{\mathrm{i}}$ is The role of the tax author-

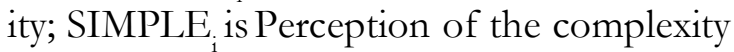
of the tax system

\begin{tabular}{|c|c|c|}
\hline Variables & Symbol & Descriptions \\
\hline $\begin{array}{l}\text { Tax evasion } \\
\text { (Dependent } \\
\text { variable) }\end{array}$ & TE & $\begin{array}{l}\text { Total score was derived through a set of } 26 \\
\text { direct questions. Minimum total score for each } \\
\text { respondent is } 26 \text { ( } 1 \text { mark times } 26 \text { questions - } \\
\text { non-compliant) and maximum total score is } 130 \\
\text { ( } 5 \text { times } 26 \text { questions- very compliant) }\end{array}$ \\
\hline $\begin{array}{l}\text { Probability of } \\
\text { being detected } \\
\text { (E1) }\end{array}$ & PROBDETECT & $\begin{array}{l}\text { Probability of a taxpayer being detected or } \\
\text { investigated by the tax authority. Minimum } \\
\text { score is } 1 \text { (non-complaint), and maximum is } 15 \\
\text { (very complaint) }\end{array}$ \\
\hline $\begin{array}{l}\text { The role of the } \\
\text { tax authority } \\
\text { (E2) }\end{array}$ & ROLE & $\begin{array}{l}\text { The role of the tax authority in administering } \\
\text { the tax system (efficiency, refunds, response to } \\
\text { complaints, customer services etc). Minimum } \\
\text { score is } 1 \text { (non-complaint), and maximum is } 15 \\
\text { (very complaint) }\end{array}$ \\
\hline $\begin{array}{l}\text { Complexity of } \\
\text { tax system (E3) }\end{array}$ & SIMPLE & $\begin{array}{l}\text { Taxpayers' perceptions on the complexity of the } \\
\text { tax system or tax returns. Minimum score is } 1 \\
\text { (non-complaint), and maximum is } 15 \text { (very } \\
\text { complaint) }\end{array}$ \\
\hline
\end{tabular}

Table 1. A Description of The Variables

${ }^{9}$ Compliant taxpayers were measured if they answered 'Agree' ( 5 on the Likert scale) or 'Strongly disagree' (1 on the Likert scale) depending on the questions. 


\section{Results}

From the surveys distributed, 71 were returned because they were incorrectly addressed, or the intended respondents had moved or died. Out of the other 1,106 surveys returned, 1,073 representing 19.51 percent of the total sample were usable and could be further analyzed. In terms of the number of surveys distributed, 5,500 was far from the total population of Malaysia, particularly the individual taxpayers who numbered 5,561,086 ${ }^{10}$ in 2011 (IRB Annual Report 2011). However, a past study (Loo 2006) showed that using such a number of questionnaires for the sample distribution was large enough to represent the individual taxpayers in Malaysia. In addition, Sekaran (2000: 295) suggested that the optimum sample size for a total population of one million should be 384 or 0.0384 percent (p.295). Knofczynski and Mundfrom (2008) provided some guidelines as to the minimum sample size needed for accurate predictions using multiple regressions. They suggested that in order to obtain a valid and good prediction using multiple regressions, the size of the sample should be determined by the number of predictors in the multiple regressions. As this study attempted to analysis three predictors, Knofczynski and Mundfrom (2008) suggested that the size of the sample should be 900 (see Knofczynski and Mundfrom (2008), p. 438).

The respondents comprised of 588 $(55 \%)$ females, $483(45 \%)$ males while 2 respondents did not mention their gender. The majority of the respondents were Malays with 910 (85\%), followed by Chinese, Indian and other ethnicities with 84 (8\%), 44 (4\%) and $32(3 \%)$ respectively. There were eight age groups involved in this study with a 5-year range in each group except for the 'above 56 years old' category. The largest group of respondents, (252 or $24 \%$ ) was aged between 26 and 30 years old and respondents in the group above 56 years old had the lowest number with 14 responses (1\%). Cumulatively, respondents aged between 20 and 40 years old made up the largest portion with 749 responses $(70 \%)$. A total of $768(72 \%)$ respondents were married, $280(26 \%)$ were single and $20(2 \%)$ were widows/widowers. The majority $(944,88 \%)$ of the respondents earned less than RM6,000 per month, while $64(6 \%)$ respondents had a monthly income

\section{Table 2. Pearson Correlation Matrix for the Dependent (TE) and Independent Vari- ables}

\begin{tabular}{|c|c|c|c|c|}
\hline & 1 & 2 & 3 & 4 \\
\hline 1. $T E$ & 1 & & & \\
\hline PROBDETECT & $-0.297(* *)$ & 1 & & \\
\hline$R O L E$ & $0.073(* *)$ & -0.012 & 1 & \\
\hline 4. SIMPLE & $0.391(* *)$ & $0.383(* *)$ & $-0.097(* *)$ & 1 \\
\hline
\end{tabular}

Note: * Correlation is significant at the 0.05 level (2-tailed); ** Correlation is significant at the 0.01 level (2-tailed).

\footnotetext{
${ }^{10}$ This figure is based on total number of tax returns distributed to registered individual taxpayers.
} 
of more than RM6,000. Only 19 (2\%) earned more than RM10,000 per month. ${ }^{11}$

Table 2 illustrates the Pearson correlation matrix for dependent and independent variables. Based on Table 2 , it provides the results of the tax evasion determinants in which all the independent variables were found to be significantly correlated with TE $(p<0.01)$. The coefficient of correlation between each independent variable and TE was stable at between $r=0.073$ to $r=-0.391$. The highest correlation occurred between TE and SIMPLE $(r=-0.391)$ followed by PROBDETECT and ROLE.

Based on the stepwise multiple regressions, the results in Table 3 indicate that the model is significant at the $\mathrm{p}<0.01$ level $(\mathrm{F}$ statistic 114.835), while $\mathrm{R}$ is estimated at 0.424 . The results suggested that tax evasion was influenced by two variables namely
PROBDETECT, and SIMPLE. The stepwise multiple regression also suggests that SIMPLE becomes the main factor with a Beta coefficient of 1.357 followed by PROBDETECT $(b=-0.263)$. The findings of this study suggest that the role of the Malaysian government in minimizing tax evasion is minimal with an insignificant Beta coefficient. Therefore, based on the institutional factors approach, the study reveals that the probability of being detected and a simple tax system in Malaysia would minimize tax evasion activities among the individual taxpayers. A high probability of being detected and a simple tax administration would discourage tax evasion. In contrast, the Government's administration style might potentially increase tax evasion i.e. through the mismanagement of taxpayers' funds, unnecessary spending and other wasteful schemes.

Table 3. Multiple Regression and Stepwise Multiple Regression - Factors Affecting Tax Evasion

\begin{tabular}{lcccccc}
\hline & Multiple Regression & \multicolumn{3}{c}{ Stepwise Multiple Regression } \\
\hline \multicolumn{1}{c}{ Variables } & Coefficient & $\mathbf{t}$ & VIF & Coefficient & T & VIF \\
\hline (Constant) & 24.596 & 38.415 & & 25.314 & 63.819 & \\
PROBDETECT & -0.265 & $-5.756^{* *}$ & 1.173 & $-0.263^{* *}$ & 10.773 & 1.172 \\
ROLE & 0.069 & 1.428 & 1.010 & & & \\
SIMPLE & 1.339 & $-10.582^{* *}$ & 1.184 & $1.357^{* *}$ & 5.716 & 1.172 \\
& & & & & & \\
Model fit: & & & & & & \\
R & 0.424 & & & 0.422 & & \\
$\mathrm{R}^{2}$ & 0.180 & & & 0.178 & & \\
Adjusted R & 0.177 & & & 0.177 & & \\
Std. error & 4.218 & & & 4.220 & & \\
F statistic & $77.312^{* *}$ & & & & & \\
\hline
\end{tabular}

Notes: Dependent variable - Tax evasion

$*$ Significant at $\mathrm{p}<0.10 ; * *$ Significant at $\mathrm{p}<0.05 ; * * *$ Significant at $\mathrm{p}<0.01$

${ }^{11}$ The average income for all regions is approximately between RM2,001 - RM4,000 per month. 
In order to validate the study, a nonresponse bias test was conducted. Non-response bias can often occur in surveys and interviews and it requires careful management in order to produce valid and reliable results (Sydow 2006 and Donzë 2002). Previous studies (see Biemer 2001; Saris and Hagenaars 1997) have attempted to determine if there is a difference between the respondents and the non-respondents, and reported that people who responded to surveys may answer questions differently to those who do not. They have also found that late responders may answer differently than early responders, and that the differences may be due to the different levels of interest in the subject matter. Most researchers view nonresponse bias as a continuum, ranging from fast responders to slow responders (with nonresponders defining the end of the continuum). There are a number of non-response bias measurements such as an extrapolation to estimate the magnitude of bias created by non-responses, and the use of a mixed method data collection (using different methods of data collection during research, such as questionnaires and phone interviews) (see
Donzë 2002). Thus, in order to validate, verify and increase the reliability and explanatory power of the results, following Donzë (2002): $;^{12} \mathrm{Li}$ and Prabhala (2005) ${ }^{13}$ and Sydow (2006), ${ }^{14}$ and due to limitations such as different questionnaire designs and research objectives, this study measured the non-response bias through two types of responses, namely 'before follow up calls' 1 and 'after follow up calls'. Based on the analysis, the Levene's test ${ }^{16}$ indicated that the majority of the responses were insignificant which mean that the variances of the variables were constant (no significant variance different between the before follow up and after follow up calls). Thus it can be said that non-response bias does not occur in this data. In addition, the ANOVA analysis for all the variables measured was also insignificant In conclusion, the ANOVA test results were sufficiently powerful to accept the null hypothesis in which there was no significant mean difference between responses received from non-followed up and followed up respondents. Thus, a non-response bias did not occur in this study.

${ }^{12}$ Donzë (2002) attempted to introduce the methodology to correct non-response in research on KOF ETH (Swiss Economic Institute) Zurich's survey in year 2000 by using 'weighting factors' in his logit linear regression model.

${ }^{13} \mathrm{Li}$ and Prabhala (2005) reviewed the econometric model of self selection in corporate finance research particularly in random sampling. Issues such as sample selection and non-response bias were the focal point of the research.

${ }^{14}$ Sydow (2006) extended Donzë's study by collecting the same data from the same dataset of population (KOF ETH Zurich). A mixed method approach (self administered questionnaires and phone interviews) was also employed. She exercised Chi square $\left(\div^{2}\right)$ and McNemar's test and Logit models.

${ }^{15}$ Like Donzë (2002) and Sydow (2006), responses received without any follow up calls were categorized as 'respondent' while responses received after follow up calls made were categorized as 'non-respondent'

${ }^{16}$ Levene's test is used to test the homogeneity of variance. If the result is insignificant $(p>0,05)$, it means that the hypothesis of homogeneity of variance cannot be rejected. Therefore the variances of the variables are constant. Thus the assumption of non-response bias does not occur in this data (Hair et.al. 2006:432, 438; Hong 2005:75-76; Sekaran 2000:319) 


\section{Summary and Concluding Remarks}

The objective of this study was to examine the determinants of tax evasion from the institutional perspectives. Three potential determinants of tax evasion were examined in this study, namely the probability of being detected, the role of the tax authority and the complexity of the tax system. The results suggested that tax evasion was significantly influenced by the probability of being detected and the complexity of the tax system. Interestingly, the complexity of the tax system played a bigger role in decreasing evasion compared to the probability of detection (refer Table 3) thus, $H_{3}$ (a simple tax return and tax system is negatively correlated with tax evasion) is accepted. This study also suggested that a high probability of being detected could minimize tax evasion activities. On the other hand, this study evidenced that a simpler tax system could possibly reduce tax evasion and instill voluntary compliance among taxpayers. This result also suggested that other variables, such as the role of the tax authority, was no longer a significant variable in predicting tax evasion some years after the introduction of a SAS and thus, $H_{1}$ (the role (efficiency) of the tax authority is positively correlated with tax compliance) is rejected.

With regards to the probability of being detected, previous studies [for example, Allingham and Sandmo (1972); Jackson and Jaouen (1989); Shanmugam (2003); Dubin (2004); Riahi-Belkaoui (2004); Richardson (2006);; Andreoni, Erard and Feinstein (1998); Bergman (1998); Verboon, and van Dijke (2007); Eisenhauer (2008)], have found that a high probability of being detected would encourage taxpayers to be more compliant (a positive relationship) but some other studies found contradictory results i.e. a high probability of being detected would potentially decrease compliance, creating a negative association (for example Young (1994), and Slemrod et al. (2001), Braithwaite et al. (2009). In addition, Slemrod et al. (1998) did not clearly state the direction (either positive or negative). Therefore, since a high probability of being detected could discourage tax evasion, the tax authority should increase their number of audit samples so that tax evasion would decrease, the tax gap would decrease and the mission of the SAS would be achieved.

In this study, other variables such as the role of the tax authority appear not to be significantly correlated with tax evasion decisions, even though previous studies in other countries found significant associations (see Harris (1989). Governments play a central role through designing and enforcing their tax systems, and collecting taxes (Hasseldine and Li 1999: 93). For example, the role of the tax authority in minimizing the tax gap and increasing voluntary compliance was found to be very important as Hasseldine and $\mathrm{Li}$ (1999) placed the government as the main influencing factor in relation to tax evasion.

Tis study has made a contribution to the tax compliance literature by demonstrating the determinants of tax evasion using a SAS in a developing country in order to increase voluntary compliance. This study can suggest specific areas where the education of others may help to increase the overall levels of voluntary compliance using the SAS. This study further contributes by providing evidence of other key tax evasion determinants in a developing country, particularly in Asian countries that were previously under researched. These determinants, it is claimed may affect tax compliance behavior. The find- 
ings of this research could also be used as a reference for any tax regime in order to improve the management of their tax system.

The results of this study are also useful in helping a tax authority to design the best mechanism for delivering the latest information on tax regulations (i.e. advertisements in the media, websites, brochures and customer services desks) and also in achieving its goals in deciding to change the collection system to one using a SAS. It is also important for the tax authority to be kept informed of taxpayers' levels of knowledge so that it can effectively and efficiently communicate (i.e. current changes in tax laws) and design tax policies (for example, the tax rates, filing requirements, penalties etc.).

It is acknowledged that this study has a number of limitations. The use of a self-reporting survey might be less reliable, especially when the information sought (tax) is sensitive, potentially incriminating or embarrassing (Richardson 2008). The actual behavior of the subjects may vary from the responses given. While acknowledging this constraint, however, it is believed that this is the most suitable way to predict the taxpayers' compliance behavior, as direct questions (face to face) might lead the respondents to answer the questions dishonestly and could be potentially embarrassing for the respondents. Using telephone directories potentially lim- its responses through only getting the head of the households; also replies from landline telephone owners tend to include only the richer groups in the society. However, this issue has been balanced by a high number of usable responses $(1,073)$ which is relatively high compared to other similar tax studies. Future research could be conducted via a longitudinal study in which a comparison of more years might provide different results from this 'point in time' study. For example a study into how changes in levels of tax knowledge, taxpayers' financial situations and changes to the tax laws and regulations potentially affect compliance decisions could be beneficial. Using data from the tax administration and comparing this with data from questionnaires could also be beneficial as a further data source for a compliance study of this kind, although the chances of accessing data from the tax authority are very slim. In conclusion, although various studies have been undertaken to determine as accurately as possible the factors that impact upon tax compliance behavior, undoubtedly, the Government should seriously consider the characteristics of non-compliant taxpayers, review the current regulations and possibly as a result, increase audit rates and penalty rates (enforcement) as well as attempt to build good relationships with the taxpayers in seeking to improve the general tax compliance levels.

\section{References}

Aini, A. O., J. Budiman, and P. Wijayanti. 2013. Kepatuhan Wajib Pajak Badan Perusahaan Manufaktur di Semarang dalam Perspektif Tax Profesional. Paperpresented at the Proceeding Simposium Nasional Perpajakan 4, Universitas Trunojoyo, Madura. http://asp.trunojoyo.ac.id/wp-content/uploads/ 2014/03/10-KEPATUHAN-WAJIB-PAJAK-BADAN- PERUSAHAAN-MANUFAKTUR-DISEMARANG-DALAM-PERSPEKTIF-TAX-PROFESSIONAL.pdf 
Allingham, M.G., and A. Sandmo. 1972. Income tax evasion: A theoretical analysis. Journal of Public Economics 1 (3-4): 323-38.

Alm, J. 1991. A perspective on the experimental analysis of taxpayer reporting. The Accounting Review 66 (3): 577-593.

Alm, J., B. Jackson, and M. McKee. 1992. Institutional uncertainty and taxpayer compliance. American Economic Review 82 (4):1018-1026.

Andreoni, J, B. Erard, and J. Feinstein. 1998. Tax evasion. Journal of Economic Literature 36: 818-860.

Australian Tax Office.2009. Title of article?.Retrieved $10^{\text {th }}$ of November 2009, from http:/ /www.ato.gov.au/ corporate $/$ content.asp?doc $=/$ content $/ 00107941 . h t m$

Balafoutas, L., A. Beck, R. Kerschbamer, and M. Sutter. 2015. The hidden costs of tax evasion: Collaborative tax evasion in markets for expert services. Journal of Public Economics 129: 14-25.

Benk, S., T. Budak, S. Püren, and M. Erdem. 2015. Perception of tax evasion as a crime in Turkey. Journal of Money Laundering Control 18 (1): 99 - 111.

Bergman, M. 1998. Criminal law and tax evasion in Argentina: Testing the limits of deterrence. International Journal of the Sociology of Law 26: 55-74.

Bird, R. M. 1998. Administrative constraints on tax policy. In Sandford, C. (ed.), Further Key Issues in Tax Reform. Bath: Fiscal Publications.

Boll , K. 2015. Deciding on tax evasion - front line discretion and constraints. Journal of Organizational Ethnography 4 (2): 193 - 207.

Calvert, P., and A. Pope. 2005. Telephone survey research for library managers. Library Management 26 (3): $139-151$.

Cachia, C., and L. Millward. 2011. The telephone medium and semi-structured interviews: A complementary fit. Qualitative Research in Organizations and Management: An International Journal 6 (3): 265-277

Forza, C. 2002. Survey research in operations management: A process-based perspective. International Journal of Operations and Production Management 22 (2): 152-194

Clotfelter, C. T. 1983. Tax evasion and tax rates: An analysis of individual returns. The Review of Economics and Statistics LXV (3): 363-73.

Damayanti, T. W., T. Sutrisno, I. Subekti, and Z. Baridwan. 2015. The role of taxpayer's perception of the government and society to improve tax compliance. Accounting and Finance Research 4 (1): p180.

Dubin, J. A. 2004. Criminal investigation enforcement activities and taxpayer non-compliance. Paper presented at 2004 IRS Research Conference, Washington, June, 1-45.

Eisenhauer, J. G. 2008. Ethical preferences, risk aversion, and taxpayer behavior. The Journal of SocioEconomics 37: 45-63.

Ernawati, W. D., and B. Purnomosidhi. 2011. Pengaruh sikap, norma subjektif, kontrol perilaku yang dipersepsikan dan sunset policy terhadap kepatuhan wajib pajak dengan niat sebagai variabel intervening. Paper presented at the Peran dan Implementasi Statistika dalam Analisis Finansial dan Pengambilan Keputusan Bisnis, Semarang.

Fiege, E. L. 1979. How big is the irregular economy? Challenge 22: 5-13.

Groiü, R., and S. Terziü. 2014. Tax evasion in Bosnia and Herzegovina and business environment. Procedia - Social and Behavioral Sciences 119: 957 - 966. 
Gutmann, P. M. 1977. The subterranean economy. Financial Analysts Journal 33 (Nov - Dec): 26-34.

Harris, T. D. 1989. The effect of type of tax knowledge on individuals' perceptions of fairness and compliance with the federal income tax system: An empirical study. PhD Thesis, University of South Carolina.

Hasseldine, J. 1993. How do revenue audits affect tax evasion. Bulletin for International Fiscal Documentation 47: $424-35$.

Hasseldine, J., and Z. Li. 1999. More tax evasion research required in new millennium. Crime, Law and Social Change 31 (1): 91-104.

Inland Revenue Board (IRB) Malaysia (2014). Title of articl?. Retrieved $14^{\text {th }}$ of March 2014, from http:// www.hasil.gov.my.

Internal Revenues Services (IRS). 2009. Update on Reducing the Federal Tax Gap and Improving Voluntary Compliance. Retrieved $10^{\text {th }}$ of November 2009, from http://www.irs.gov/pub/newsroom/ tax_gap_report_-final_version.pdf

Isa , K. 2014. Tax complexities in the Malaysian corporate tax system: Minimize to maximize. International Journal of Law and Management 56 (1): 50 - 65.

Jackson, B., and P. Jaouen. 1989. Influencing taxpayer compliance through sanction threat or appeals to conscience. Advances in Taxation 2: 131-47.

Jackson. B. R., and V. C. Milliron. 1986. Tax evasion research: Findings, problems, and prospects. Journal of Accounting Literature 5: 125-165.

Kasipillai, J., and J. Baldry. 1998. What do Malaysian taxpayers know? Malaysian Accountant (February): 27.

Kirchler, E. 2007. The Economic Psychology of Tax Behaviour. Cambridge: Cambridge University Press.

Konfczynski, G. T., and D. Mundfrom. 2008. Sample sizes when using multiple linear regression for prediction. Educational and Psychological Measurement 68 (3): 431-42.

Lai, M-L., S. Normala, and A. K. Meera. 2005. Towards electronic tax filing: Technology readiness and responses of Malaysian tax practitioners. Tax Nasional (First Quarter): 16-23.

McBarnet, D. 2001. When Compliance Is Not the Solution But the Problem: From Changes in Law to Changes to Attitude. Canberra: Australian National University, Centre for Tax System Integrity.

Mohani, A., and P. Sheehan. 2003. Estimating the extent of income tax non-compliance in Malaysia and Australia using the gap approach (part I). Tax Nasional (4 ${ }^{\text {th }}$ Quarter): 22- 34.

Mohani, A. 2001. Personal income tax non-compliance in Malaysia. Ph.D. thesis. Victoria University: Melbourne, Australia.

Mohani, A., and P. Sheehan. 2004. Estimating the extent of income tax non-compliance in Malaysia and Australia using the gap approach (part II). Tax Nasional (1 ${ }^{\text {st }}$ Quarter): 20- 24.

Nor Azrina Mohd Yusof, L. M. Ling, and Y. B. Wah. 2014. Tax non-compliance among SMCs in Malaysia: Tax audit evidence. Journal of Applied Accounting Research 15 (2): 215 - 234

Riahi-Belkaoui, A. 2004. Relationship between tax evasion internationally and selected determinants of tax morale. Journal of International Accounting, Auditing and Taxation 13: 135-143.

Richardson, G. 2008. The relationship between culture and tax evasion across countries: Additional evidence and extensions. Journal of International Accounting, Auditing and Taxation 17 (2): 67-78. 
Ritsatos, T. 2014. Tax evasion and compliance; from the neo classical paradigm to behavioral economics, a review. Journal of Accounting and Organizational Change 10 (2): $244-262$.

Schneider, F., K. Raczkowski, and B. Mróz. 2015. Shadow economy and tax evasion in the EU. Journal of Money Laundering Control 18 (1): $34-51$.

Sekaran, U. 2000. Research Methodsfor Business; A Skill Building Approach $\left(3^{\text {rd }}\right.$ ed.). New York: John Wiley and Sons.

Shanmugam, S. 2003. Managing self assessment - an appraisal. Tax Nasional (1 ${ }^{\text {st }}$ Quarter): $30-32$.

Silvani, C., and K. Baer. 1997. Designing a tax administration reform strategy: Experiences and guidelines. Working Paper. International Monetary Funds, Washington DC.

Singh, V. 2003. Malaysian Tax Administration (6 ${ }^{\text {th }}$ ed.). Kuala Lumpur: Longman.

Slemrod, J. 1989. Complexity, compliance costs, and tax evasion. In Roth, J. A., and J. T. Scholz (eds.), Taxpayer Compliance: Social Perspectives. Philadelphia 2: 156-181.

Slemrod, J., M. Blumenthal, and C. Christian. 1998. The determinants of income tax evasion: Evidence from a control experiment in Minnesota. National Bureau of Economic Research Working Paper no. W6575.

Slemrod, J., M. Blumenthal, and C. Christian. 2001. Taxpayer response to an increased probability of audit: Evidence from a control experiment in Minnesota. Journal of Public Economics 79: 455-483.

Song, Y. D., and T. E. Yarbrough. 1978. Tax ethics and taxpayer attitudes: A survey. Public Administration Review 38 (5): 442-452.

South East Asian Mobile Communications \& Mobile Data Markets Report. 2013.

Spicer, M. W., and S. B. Lundstedt. 1976. Understanding tax evasion. Public Finance 31 (2): 295-305.

Stack , G. 2015. Money laundering in Ukraine. Journal of Money Laundering Control 18 (3): 382-394.

Verboon, P., and M. Van Dijke. 2007. A self-interest analysis of justice and compliance: How distributive justice moderates the effect of outcome favorability. Journal of Economic Psychology 28: 704-727.

Wang, C. L., and M. N. K Saunders. 2012. Non-response in cross-cultural surveys: Reflections on telephone survey interviews with Chinese managers. In Catherine L. Wang, David J. Ketchen, Donald D. Bergh (Ed.), West Meets East: Toward Methodological Exchange (Research Methodology in Strategy and Management 7: 213-237). Emerald Group Publishing Limited.

Young, J. C. 1994. Factors associated with non-compliance: Evidence from the Michigan tax amnesty program. Journal of American Taxation Association 16 (2): 82-105. 
